\title{
Drug Repurposing Screen for Compounds Inhibiting the Cytopathic Effect of SARS-CoV-2
}

Catherine Z. Chen ${ }^{1 *}$, Paul Shinn ${ }^{1}$, Zina Itkin ${ }^{1}$, Richard T. Eastman ${ }^{1}$, Robert Bostwick ${ }^{2}$, Lynn Rasmussen $^{2}$, Ruili Huang ${ }^{1}$, Min Shen $^{1}$, Xin Hu$^{1}$, Kelli M. Wilson ${ }^{1}$, Brianna Brooks ${ }^{1}$, Hui Guo ${ }^{1}$, Tongan Zhao ${ }^{1}$, Carleen Klump-Thomas ${ }^{1}$, Anton Simeonov ${ }^{1}$, Samuel G. Michael ${ }^{1}$, Donald C. Lo ${ }^{1}$, Matthew D. Hall ${ }^{1}$, Wei Zheng ${ }^{1^{*}}$

${ }^{1}$ National Center for Advancing Translational Sciences, 9800 Medical Center Drive, Rockville, MD, 20850.

${ }^{2}$ Southern Research, 2000 Ninth Avenue South, Birmingham, Alabama, 35205.

*To whom correspondence should be addressed:

Catherine Chen - Catherine.chen@nih.gov

Wei Zheng -wzheng@mail.nih.gov

Running title: Drug repurposing screen for SARS-CoV-2 


\section{Abstract}

Drug repurposing is a rapid approach to identifying therapeutics for the treatment of emerging infectious diseases such as COVID-19. To address the urgent need for treatment options, we carried out a quantitative high-throughput screen using a SARS-CoV-2 cytopathic assay with a compound collection of 8,810 approved and investigational drugs, mechanism-based bioactive compounds, and natural products. Three hundred and nineteen compounds with anti-SARSCoV-2 activities were identified and confirmed, including 91 approved drug and 49 investigational drugs. Among these confirmed compounds, the anti-SARS-CoV-2 activities of 230 compounds, including 38 approved drugs, have not been previously reported.

Chlorprothixene, methotrimeprazine, and piperacetazine were the three most potent FDA approved drugs with anti-SARS-CoV-2 activities. These three compounds have not been previously reported to have anti-SARS-CoV-2 activities, although their antiviral activities against SARS-CoV and Ebola virus have been reported. These results demonstrate that this comprehensive data set of drug repurposing screen for SARS-CoV-2 is useful for drug repurposing efforts including design of new drug combinations for clinical trials.

Keywords: COVID-19, SARS-CoV-2, cytopathic effect, drug repurposing screen 


\section{Introduction}

The coronavirus disease 2019 (COVID-19) pandemic caused by severe acute respiratory syndrome coronavirus 2 (SARS-CoV-2) has become a global health crisis. As of July 31, 2020, the global case report stands at 17.5 million, with a death toll of 677,538 (Dong et al., 2020). Only remdesivir, an investigational drug developed for Ebola virus, has been granted emergency use authorization by the US FDA (Eastman et al., 2020). Since neither an effective vaccine, nor antiviral therapy, are currently available for COVID-19, drug repurposing has received significant attention in the rapid search to fill this unmet therapeutic need.

The requirement of biosafety level 3 (BSL-3) containment laboratories for handling SARS-CoV-2 has limited the number of high throughput screening (HTS) laboratories that are capable of carrying out large scale compound screens using live SARS-CoV-2. Despite these challenges, several drug repurposing screens have been carried out using live SARS-CoV-2, showing promising results (Dittmar et al., 2020; Ellinger et al., 2020; Riva et al., 2020; Touret et al., 2020). Here we report a screening campaign against a collection of 8,810 approved and investigational drugs, mechanism-based bioactive compounds, and natural products that was carried out in quantitative HTS (qHTS) format (Inglese et al., 2006). Compounds were screened at four concentrations in a SARS-CoV-2 cytopathic effect (CPE) assay in Vero E6 cells that were selected for high ACE2 expression, with an accompanying cytotoxicity counter-assay. The primary screen yielded 319 hits with confirmed anti-SARS-CoV-2 activity. The primary screening data have been made publicly available on the NCATS OpenData Portal (https://opendata.ncats.nih.gov/covid19/index.html) (Brimacombe et al., 2020). We intend this as a companion to guide investigators in utilizing that data, and to present further details of qHTS with the SARS-CoV-2 CPE assay, including identification of top annotated hits.

\section{Materials and Methods}

\section{Compounds and compound libraries}


All compound libraries were assembled internally at NCATS. The NCATS pharmaceutical collection (NPC) contains 2,678 compounds, covering drugs approved by US FDA and foreign health agencies in European Union, United Kingdom, Japan, Canada, and Australia, as well as some clinical trialed experimental drugs (Huang et al., 2019). The NCATS Mechanism Interrogation Plate (MIPE) 5.0 library contains 2,480 mechanism based bioactive compounds, targeting more than 860 distinct mechanisms of action (Lin et al., 2019). The NCATS Pharmacologically Active Chemical Toolbox (NPACT) is a library of mechanistically defined molecules and natural products (5,099 compounds). Other small custom NCATS collections were also screened: anti-infective (752 compounds), kinase inhibitors (977 compounds), epigenetic modulators (335 compounds). A commercially available autophagy-focused screening library (Cayman \#23537) was analyzed and 29 compounds that were not already present in our collections were purchased. All compounds were dissolved in DMSO to make 10 $\mathrm{mM}$ stock solutions, unless solubility was limiting, and was diluted four times at 1:5 ratio for the primary screens, and at 1:3 ratio for follow up assays at 8 concentrations.

\section{CPE assay}

A SARS-CoV-2 CPE assay was conducted in the BSL3 facilities at the contract research organization Southern Research (Birmingham, AL). Briefly, compounds were titrated in DMSO and acoustically dispensed into 384-well assay plates at $60 \mathrm{~nL} /$ well at NCATS, and provided to Southern Research. Cell culture media (MEM, 1\% Pen/Strep/GlutaMax, 1\% HEPES, 2\% HI FBS) was dispensed at $5 \mu \mathrm{L} /$ well into assay plates and incubated at room temperature to allow for compound dissolution. Vero E6 African green monkey kidney epithelial cells (selected for high ACE2 expression) were inoculated with SARS CoV-2 (USA_WA1/2020) at multiplicity of infection (MOI) of 0.002 in media and quickly dispensed into assay plates as $25 \mu \mathrm{L} /$ well. The final cell density was 4000 cells/well. Assay plates were incubated for $72 \mathrm{~h}$ at $37 \mathrm{C}, 5 \% \mathrm{CO}_{2}, 90 \%$ humidity. CellTiter-Glo (30 $\mu \mathrm{L} /$ well, Promega \#G7573) was dispensed into the assay plate. Plates were incubated for $10 \mathrm{~min}$ at room temperature. Luminescence signal was measured on Perkin Elmer Envision or BMG CLARIOstar plate readers. An ATP content cytotoxicity counter-assay 
was conducted using the same protocol as the CPE assay, without the addition of SARS-CoV-2 virus.

\section{Data analysis}

Results from the primary screen and confirmation screens were processed at NCATS using a software developed in-house (Wang et al., 2010). For the CPE assay, raw plate data were normalized with DMSO-only wells as $0 \%$ CPE rescue (negative signal control) and no virus control wells as $100 \%$ CPE rescue (positive signal control). For the cytotoxicity assay, raw plate data were normalized with DMSO-only wells as $100 \%$ viability (positive signal control) and cells treated with hyamine (benzethonium chloride) control compound as $0 \%$ viability (negative signal control). The half-maximum effective values $\left(\mathrm{EC}_{50}\right)$ and percent efficacy were obtained by fitting the concentration-response titration data to a four-parameter Hill equation. Compounds with $>55 \%$ efficacy were selected for cherry-pick confirmation. The concentration-response curves of re-tested compounds were also plotted using GraphPad Prism 9 (GraphPad Software Inc., San Diego, CA). Results in the figures are expressed as mean \pm standard deviation (SD).

\section{Results}

\section{High throughput screening with SARS-CoV-2 CPE assay}

Our aims were two-fold in initiating this program. The first was to identify active compounds that may provide opportunities for repurposing or identify mechanistic targets of interest. The second was to create a complete HTS reference dataset that can be shared openly with the scientific community. The CPE reduction assay format has been widely employed to screen for antiviral agents due to its easy of scalability for HTS (Heaton, 2017). In this assay, viral infection kills host cells and the cell viability is used as a surrogate readout for viral infection and replication. In other words, compounds with anti-viral activity rescue cells from the cytopathic effect of SARS-CoV-2 (a gain-of-signal assay). 
A total of 9,952 compounds were tested in the primary screen, but due to overlap in the composition of libraries, a significant number of compounds were tested multiply. A total of 8,810 unique compounds in six compound libraries were tested in the primary screen including the NCATS Pharmaceutical Collection (NPC), NCATS Mechanism Interrogation Plate (MIPE), NCATS Pharmacologically Active Chemical Toolbox (NPACT), Epigenomic library, Autophagy library, and anti-infective library. These compounds contain 1,345 approved drugs (by FDA, EMA, DPD), 751 compounds approved outside of these countries, 1067 investigational drugs (in clinical trials), 1057 pre-clinical compounds (tested in animals) and 4,472 bioactive compounds (tool compounds) (Figure 1a). By their mechanisms of action and clinical application, these compounds are divided into diverse groups (Figure 1b).

The CPE assay performed well in the primary screen, with an average $Z^{\prime}$ factor of 0.83 over 133 plates over three batched runs (Figure 2a). Remdesivir concentration response was included as a control for each screening run and yielded consistent EC50 values of $4.56 \mu \mathrm{M}, 4.42 \mu \mathrm{M}$ and $7.28 \mu \mathrm{M}$ (Figure $2 \mathrm{~b}$ ). Using the criteria of $>55 \%$ efficacy, 380 compounds were selected as the primary screen hits, out of which, 319 compounds were confirmed using 8-point, 1:3 titration in duplicate. Among these primary hits, 89 of 319 had previously reported activity against SARSCoV-2, including the assays of live virus, enzymatic, or virtual screening, while 230 were novel hits from this qHTS (Table $1, \mathrm{~S} 1$ ).

\section{1 approved drugs and 49 investigational drugs protected against cytopathic effect of SARS-}

\section{CoV-2 infection}

There were 56 top confirmed hits with $\mathrm{EC}_{50}$ values of $\leq 10 \mu \mathrm{M}$ and efficacy greater than $80 \%$ in the CPE assay, and greater than 10-fold selectivity index between cytotoxicity and CPE assays (Table 1, Figure 3). When grouped by mechanism of action targets, 19 compounds were GPCR modulators, 8 were host protease inhibitors, 5 were kinase modulators, and 3 were autophagy modulators (Figure 3). Interestingly, in the 56 top hits, only one, remdesivir has a known viral target as a known primary mechanism, whereas the known mechanisms of action of the other compounds are directed against host targets. 
There have been several previous drug repurposing screens reported for SARS-CoV-2 in 2D cell culture infection models (Dittmar et al., 2020; Ellinger et al., 2020; Jeon et al., 2020; Riva et al., 2020; Touret et al., 2020; Weston et al., 2020). These screens had some compound overlap with our qHTS screen, particularly for the FDA approved drugs. We performed a literature search of our confirmed compounds and previous reports were noted in Table 1 and Table S1. Three of the top 56 hits were novel and FDA approved. These hits are chlorprothixene, methotrimeprazine, and piperacetazine, which showed $10 \mu \mathrm{M}$ potencies in the CPE assay. Four drugs approved outside of the US were also identified as novel compounds with anti-SARS-CoV2 effects: difeterol, rescimetol, melitracen $\mathrm{HCl}$, and proglumetacin. Furthermore, we identified 7 novel clinical trial drugs with anti-SARS-CoV-2 activities: N-methylspiperone HCl, Lu AE58054 $\mathrm{HCl}$, balicatib, berzosertib, JTV519 hemifumarate, DMP 777, and dexanabinol. In addition to above novel hits, four drugs, approved by FDA and elsewhere, methdilazine, maprotiline $\mathrm{HCl}$, deserpidine, and flunarizine, were previously reported in virtual screens against SARS-CoV-2 targets without supporting biological data. Here, we report their activities against SARS-CoV-2 infection. In addition, we have confirmed 53 approved drugs with anti-SARS-CoV-2 drugs that were reported previously (Table 1 and Table S1). Together, our results demonstrate a comprehensive set of 91 approved drugs and 49 investigational drugs with anti-SARS-CoV-2 activity that can be considered for design of new clinical trials, especially drug combination therapies, to increase and improve treatment options for COVID-19.

\section{Discussion}

In contrast to the other reported drug repurposing screens for SARS-CoV-2 using a single drug concentration in the primary screens (Dittmar et al., 2020; Ellinger et al., 2020; Jeon et al., 2020; Riva et al., 2020; Touret et al., 2020; Weston et al., 2020), we have used a quantitative HTS (qHTS, concentration-response) method (Inglese et al., 2006) where four compound concentrations were used in the primary screen instead of a single compound concentration. We also assessed the cytotoxicity of each compound against Vero E6 cells (without virus infection) in parallel with the SARS-CoV-2 CPE screening. The concentration-response for each 
compound used in the primary screen can improve identification of positive hits, especially these compounds with biphasic actions (bell-shaped curves) or screening errors. In addition, we have more inclusive compound collections with drugs approved by regulatory agencies outside of USA, such as Canada, Europe and Japan, that were not previously screened in SARS-CoV-2 assays. We also screened a set of investigational drugs that have human clinical data for drug properties such as the mechanism(s) of action, pharmacokinetics, and drug toxicity, which could be leveraged to speed up drug development. The other bioactive compounds screened have drug targets and mechanisms of action that may be useful for further studies of disease pathophysiology and for potential drug development.

We identified 319 compounds with activity against SARS-CoV-2 CPE from a qHTS of 8,810 unique compounds. Among the top 56 hits identified with $<10 \mu \mathrm{M} \mathrm{EC} \mathrm{F}_{50}$ values and $>80 \%$ efficacies, the anti-SARS-CoV-2 activity of 37 of them has not been reported elsewhere. Of these novel top hits, three were FDA approved drugs with novel anti-SARS-CoV-2 activity. Chlorprothixene is a dopamine receptor antagonist, a classic antipsychotic agent approved for treatment of schizophrenia (Schrijver et al., 2016). Methotrimeprazine, also named as levomepromazine, is another tricyclic antipsychotic agent approved for psychotic disorders including schizophrenia, and manic-depressive syndromes (Sivaraman et al., 2010). Both chlorprothixene and methotrimeprazine were previously found to inhibit the SARS-CoV replication with $\mathrm{EC}_{50}$ s around $10 \mu \mathrm{M}$ (Barnard et al., 2008). Piperacetazine is also an older tricyclic antipsychotic drug approved for treatment of schizophrenia (Eslami Shahrbabaki et al., 2018). The antiviral effect of piperacetazine was found previously that blocked the Ebola viral entry with the $\mathrm{EC}_{50}$ of $9.68 \mu \mathrm{M}$ (Kouznetsova et al., 2019).

We also confirmed the anti-SARS-CoV-2 activity of 5 compounds that were reported as virtual screening hits but had yet to be confirmed experimentally, including methdilazine by an Al prediction algorithm (Grzybowski et al., 2020), GMC 2-113 by a virtual screen of RNA dependent RNA polymerase (RdRP) (Dwivedy et al., 2020), maprotiline by a main protease docking (Chauhan, 2020), deserpidine by a NPS-16 docking (Jiang et al., 2020), and flunarizine by a spike protein docking screen (Chernyshev, 2020). Our data supports the utility of these emerging technologies and the field of Al for advancing drug development. 
For in vitro screens of antiviral compounds, molecular target (mechanism) based assays and phenotypic assays are two major approaches. Common targets are viral enzymes such as viral protease, DNA and RNA polymerases, reverse transcriptase, and integrase. Development of assays targeting viral enzymes rely on viral enzyme expression, purification, assay development, and validation (Shyr et al., 2020). Alternatively, phenotypic assays involving live virus infections are readily executed once the viruses are isolated from patients and viral replication in appropriate host cells are established. A common live virus infection assay is the measurement of CPE in virus infected host cells. There are two possibilities (fates) for the host cells after viral infection, including cytopathic infection (i.e. death of host cells) and persistent infection (Heaton, 2017). The CPE effect can be readily measured by the ATP content cell viability assay, which is robust and amenable for HTS. Due to the nature of the CPE assay, compounds that suppress CPE can act against any part of the virus infection cycle, including the binding of virus to host cell receptor, entry into host cells, virus replication, viral assembly/budding, and virus reinfection of adjacent cells.

It is worth briefly reflecting on the limitations of the drug repurposing assay approach. A number of small molecules of interest for treating COVID19 that are currently in clinical trials were not hits in our assay. For example, the TMPRSS2 inhibitors camostat and nafamstat are protease inhibitors approved in Japan for treating pancreatitis, and known to inhibit TMPRSS2 (Shrimp et al., 2020). While TMPRSS2 is reported to be a mediator of SARS-CoV-2 cell entry, Vero E6 cells do not express TMPRSS2, so this class of compound are not active in the Vero E6 assay. The drug efflux transporter P-glycoprotein (P-gp) can reduce cellular concentrations of test agents, and as a kidney epithelial cell line, Vero E6 cells likely expresses significant P-gp concentrations, which would reduce activity of P-gp substrates (Robey et al., 2018). Remdesivir itself is a substrate of Pgp (EMA, 2020), and is weaker against SARS-CoV-2 in assays using Vero E6 cells $\left(\mathrm{EC}_{50}>1 \mu \mathrm{M}\right)$ compared with Calu-3 or Huh7 cell lines $\left(\mathrm{EC}_{50}>50 \mathrm{nM}\right)$ (2020). These examples highlight the need for careful interpretation and critical follow-up studies after initial high-throughput screening analyses.

Importantly, the comprehensive primary screen datasets of this study for approved and investigational drugs, and mechanism-based bioactive compounds have been made publicly 
available in real-time on the NCATS OpenData Portal

(https://opendata.ncats.nih.gov/covid19/index.html) (Brimacombe et al., 2020). These datasets

provide a wealth of quality live-virus data that is freely available to the research community for

future studies and data mining with the aim of offering a new medicine to treat COVID-19

patients quickly and safely (Huang et al., 2020; Zhu et al., 2020a).

\section{Acknowledgements}

This work was supported by the Intramural Research Program of National Center for Advancing Translational Sciences, National Institutes of Health, Bethesda, MD, USA.

\section{Author contributions}

PS, ZI, RTE prepared the assay ready plates. RB and LR conducted the CPE and cytotoxicity assays. PS, CK-T, KMW and SGM curated the compound libraries. CZC and MDH designed the experiments. CZC, BB, WZ wrote the manuscript. $\mathrm{RH}, \mathrm{MS}, \mathrm{XH}, \mathrm{HG}, \mathrm{TZ}$ performed data analysis and data uploads. All authors provided critical reading of the manuscript. 


\section{Figure legends}

Figure 1. Compound library description. (a) By approval status: approved drug (FDA and others), clinical trial, preclinical. (b) By mechanism of action.

Figure 2. Control compounds reproducibility. Concentration response curve fittings for remdesivir in four independent runs for primary screens and hit confirmation. EC50 values of 4.56 $\mu \mathrm{M}, 4.42 \mu \mathrm{M}, 7.28 \mu \mathrm{M}$, and 5.17 $\mu \mathrm{M}$ of remdesivir in the CPE assay demonstrate day-today reproducibility of the assay.

Figure 3. Compounds concentration response curves in the CPE assay. (a) Autophagy modulators, (b) host protease inhibitors, (c) kinase modulators, (d) opioid receptor modulators, (e) serotonin receptor modulators, (f) histamine receptor modulators, and (g) dopamine and other GPCR receptor modulators. Berzosertib, VPS34-IN1, and STF-62247 showed bell-shaped concentration response due to cytotoxicity. No other compounds caused any reduction in viability in the cytotoxicity assay. 


\section{Table 1. Top confirmed anti-SARS-CoV-2 compounds}

\begin{tabular}{|c|c|c|c|c|c|c|c|c|}
\hline Sample ID & Sample Name & $\begin{array}{l}\text { CPE } \\
\text { EC50 } \\
(\mathbf{u M})\end{array}$ & $\begin{array}{l}\text { CPE \% } \\
\text { Efficacy }\end{array}$ & $\begin{array}{c}\text { Cytotox } \\
\text { CC50 } \\
(\mathbf{u M})\end{array}$ & $\begin{array}{c}\% \\
\text { Cytotox }\end{array}$ & $\begin{array}{l}\text { Previous reports } \\
\text { against CoVs }\end{array}$ & $\begin{array}{l}\text { Approval } \\
\text { status }\end{array}$ & MOA \\
\hline \multicolumn{9}{|l|}{ Viral Target } \\
\hline NCGC00686694 & Remdesivir & 10.0 & 133.1 & N/A & $<30$ & $\begin{array}{l}\text { Clinical (Beigel et } \\
\text { al., 2020) }\end{array}$ & FDA EUA & RdRP inhibitor \\
\hline \multicolumn{9}{|c|}{ Autophagy Modulators } \\
\hline NCGC00387732 & VPS34-IN1 & 0.63 & 103.0 & 10.0 & -76.5 & None & Bioactive & Autophagy modulator \\
\hline NCGC00344081 & STF-62247 & 1.1 & 107.1 & 11.2 & -56.6 & None & Preclinical & $\begin{array}{l}\text { Autophagy modulator; Renal } \\
\text { cell growth inhibition }\end{array}$ \\
\hline NCGC00507892 & $\begin{array}{l}\text { VPS34 } \\
\text { Inhibitor } 1\end{array}$ & 1.4 & 98.3 & N/A & $<30$ & None & Preclinical & Autophagy modulator \\
\hline \multicolumn{9}{|c|}{ GPCR Modulators } \\
\hline NCGC00346896 & MCOPPB & 3.5 & 85.6 & N/A & $<30$ & None & Preclinical & ORL1 (OP4, NOP) Agonists \\
\hline NCGC00370950 & GW 803430 & 3.5 & 93.3 & N/A & $<30$ & None & Bioactive & $\begin{array}{l}\text { Melanin-concentrating hormone } \\
\text { receptor } 1 \text { Antagonist }\end{array}$ \\
\hline NCGC00017063 & $\begin{array}{l}\text { Amodiaquin } \\
\text { dihydrochloride }\end{array}$ & 4.0 & 87.2 & N/A & $<30$ & $\begin{array}{l}\text { In vitro live virus } \\
\text { (Weston et al., } \\
2020 \text { ) }\end{array}$ & FDA & Histamine receptor antagonist \\
\hline NCGC00485045 & $\begin{array}{l}\mathrm{N}- \\
\text { Methylspiperon } \\
\text { e hydrochloride }\end{array}$ & 4.5 & 80.0 & N/A & $<30$ & None & Clinical trial & $\begin{array}{l}\text { Serotonin } 2 \text { (5-HT2) receptor } \\
\text { Antagonist }\end{array}$ \\
\hline NCGC00016710 & $\begin{array}{l}\text { Clemastine } \\
\text { fumarate }\end{array}$ & 7.9 & 96.0 & N/A & $<30$ & $\begin{array}{l}\text { Mpro assay } \\
\text { (Vatansever et al., } \\
\text { 2020) }\end{array}$ & FDA & Histamine receptor antagonist \\
\hline NCGC00386477 & GMC 2-29 & 7.9 & 117.2 & N/A & $<30$ & None & Bioactive & $\begin{array}{l}\text { 5-hydroxytryptamine receptor } \\
\text { 1D Antagonist }\end{array}$ \\
\hline NCGC00378842 & $\begin{array}{l}\text { Lu AE58054 } \\
\text { hydrochloride }\end{array}$ & 10.0 & 97.2 & N/A & $<30$ & None & Clinical trial & $\begin{array}{l}\text { Serotonin } 6 \text { (5-HT6) receptor } \\
\text { Antagonist }\end{array}$ \\
\hline NCGC00013683 & $\begin{array}{l}\text { Chlorprothixen } \\
\text { e }\end{array}$ & 10.0 & 104.4 & N/A & $<30$ & None & FDA & Dopamine receptor antagonist \\
\hline NCGC00014482 & $\begin{array}{l}\text { Methdilazine } \\
\text { hydrochloride }\end{array}$ & 10.0 & 86.4 & N/A & $<30$ & $\begin{array}{l}\text { Virtual: AI } \\
\text { prediction } \\
\text { (Grzybowski et al., } \\
2020 \text { ) }\end{array}$ & FDA & Antihistamine \\
\hline NCGC00179370 & $\begin{array}{l}\text { Methotrimepra } \\
\text { zine maleate }\end{array}$ & 10.0 & 84.6 & N/A & $<30$ & None & FDA & $\begin{array}{l}\text { Antagonist for adrenergic, } \\
\text { dopamine, histamine, } \\
\text { cholinergic and serotonin (5- } \\
\text { hydroxytryptamine; 5-HT) } \\
\text { receptors }\end{array}$ \\
\hline NCGC00016642 & Piperacetazine & 10.0 & 103.7 & N/A & $<30$ & None & FDA & Dopamine receptor antagonist \\
\hline NCGC00181913 & Difeterol & 10.0 & 113.4 & N/A & $<30$ & None & $\begin{array}{l}\text { Approved } \\
\text { outside of US }\end{array}$ & Antihistamine \\
\hline NCGC00386484 & $\begin{array}{l}\text { (R)-(-)-LY } \\
426965 \\
\text { dihydrochloride }\end{array}$ & 10.0 & 110.7 & N/A & $<30$ & None & Bioactive & $\begin{array}{l}\text { Serotonin } 2 b(5-\mathrm{HT} 2 \mathrm{~b}) \text { receptor } \\
\text { Modulator }\end{array}$ \\
\hline NCGC00015608 & $\begin{array}{l}\text { Loperamide } \\
\text { hydrochloride }\end{array}$ & 10.0 & 98.6 & N/A & $<30$ & $\begin{array}{l}\text { In vitro live virus } \\
\text { (Jeon et al., 2020) }\end{array}$ & FDA & Opioid receptor agonist \\
\hline NCGC00485321 & $\begin{array}{l}\text { Naltrindole } \\
\text { isothiocyanate } \\
\text { hydrochloride }\end{array}$ & 10.0 & 114.7 & N/A & $<30$ & None & Bioactive & $\begin{array}{l}\text { Delta opioid receptor } \\
\text { Antagonist }\end{array}$ \\
\hline NCGC00165726 & AM1241 & 10.0 & 97.6 & N/A & $<30$ & None & Bioactive & $\begin{array}{l}\text { Cannabinoid CB2 receptor } \\
\text { Agonist }\end{array}$ \\
\hline NCGC00386703 & $\begin{array}{l}\text { CpdD } \\
\text { hydrochloride }\end{array}$ & 10.0 & 96.9 & N/A & $<30$ & None & Bioactive & Ghrelin receptor Antagonist \\
\hline NCGC00386219 & $\begin{array}{l}\text { SB } 271046 \\
\text { hydrochloride }\end{array}$ & 10.0 & 107.5 & N/A & $<30$ & None & Bioactive & $\begin{array}{l}\text { Serotonin 6 (5-HT6) receptor } \\
\text { Antagonist }\end{array}$ \\
\hline NCGC00386479 & GMC 2-113 & 10.0 & 129.7 & N/A & $<30$ & $\begin{array}{l}\text { Virtual: RdRP } \\
\text { (Dwivedy et al., } \\
\text { 2020) }\end{array}$ & Bioactive & $\begin{array}{l}\text { 5-hydroxytryptamine receptor } \\
\text { 1D Antagonist }\end{array}$ \\
\hline
\end{tabular}


bioRxiv preprint doi: https://doi.org/10.1101/2020.08.18.255877; this version posted August 18, 2020. The copyright holder for this preprint

\begin{tabular}{|c|c|c|c|c|c|c|c|c|}
\hline NCGC00386330 & Z-FA-FMK & 0.13 & 104.8 & N/A & $<30$ & $\begin{array}{l}\text { Mpro assay, in vitro } \\
\text { live virus (Zhu et } \\
\text { al., 2020b) }\end{array}$ & Bioactive & Cathepsin L Inhibitor \\
\hline NCGC00485951 & VBY-825 & 0.14 & 97.8 & N/A & $<30$ & $\begin{array}{l}\text { In vitro live virus } \\
\text { (Riva et al., 2020) }\end{array}$ & Clinical trial & Cathepsin S Inhibitor \\
\hline NCGC00345807 & CAA- 0225 & 0.20 & 99.3 & N/A & $<30$ & None & Preclinical & Cathepsin L Inhibitors \\
\hline NCGC00386232 & $\begin{array}{l}\text { Cathepsin } \\
\text { Inhibitor } 1\end{array}$ & 0.25 & 114.4 & N/A & $<30$ & None & Bioactive & Cathepsin inhibitors \\
\hline NCGC00163432 & Calpeptin & 0.50 & 111.7 & N/A & $<30$ & $\begin{array}{l}\text { Mpro assay, in vitro } \\
\text { live virus (Ma et al., } \\
\text { 2020) }\end{array}$ & Preclinical & Calpain inhibitor \\
\hline NCGC00485375 & $\begin{array}{l}\text { Z-Gly-Leu- } \\
\text { Phe- } \\
\text { chloromethyl } \\
\text { ketone }\end{array}$ & 1.3 & 87.2 & N/A & $<30$ & None & Bioactive & Granzyme B Inhibitor \\
\hline NCGC00371151 & Balicatib & 2.0 & 100.3 & N/A & $<30$ & None & Clinical trial & $\begin{array}{l}\text { Cruzipain (Trypanosoma cruzi) } \\
\text { Inhibitor }\end{array}$ \\
\hline NCGC0016166 & $\begin{array}{l}\text { Calpain } \\
\text { Inhibitor I, } \\
\text { ALLN }\end{array}$ & 2.0 & 111.1 & N/A & $<30$ & None & Bioactive & Calpain inhibitor \\
\hline \multicolumn{9}{|c|}{ Kinase Modulators } \\
\hline NCGC00263093 & Apilimod & 0.023 & 104.4 & N/A & $<30$ & $\begin{array}{l}\text { Pseudovirus assay } \\
\text { (Ou et al., 2020) }\end{array}$ & Clinical trial & $\begin{array}{l}\text { IL-12 Production Inhibitor; } \\
\text { PIKfyve inhibitor }\end{array}$ \\
\hline NCGC00386313 & Berzosertib & 0.71 & 87.9 & 11.2 & -98.5 & None & Clinical trial & ATR Kinase Inhibitor \\
\hline NCGC00347280 & $\begin{array}{l}\text { IKK-2 Inhibitor } \\
\text { VIII }\end{array}$ & 7.1 & 91.7 & N/A & $<30$ & None & Preclinical & IKK-2 (IKK-beta) Inhibitor \\
\hline NCGC00387166 & NSC 33994 & 8.9 & 107.6 & N/A & $<30$ & None & Bioactive & Jak2 Inhibitor \\
\hline NCGC00159456 & Imatinib & 10.0 & 119.0 & N/A & $<30$ & $\begin{array}{l}\text { Clinical (Morales- } \\
\text { Ortega et al., 2020) }\end{array}$ & FDA & $\begin{array}{l}\text { Bcr-Abl kinase inhibitor; KIT } \\
\text { inhibitor; PDGFR tyrosine } \\
\text { kinase receptor inhibitor }\end{array}$ \\
\hline \multicolumn{9}{|l|}{ Others } \\
\hline NCGC00178090 & Pristimerin & 0.11 & 87.4 & 1.1 & -93.2 & $\begin{array}{l}\text { SARS Mpro assay } \\
\text { (Ryu et al., 2010) }\end{array}$ & Preclinical & $\begin{array}{l}\text { Monoacylglycerol lipase } \\
\text { (MGL) inhibitor }\end{array}$ \\
\hline NCGC00385252 & $\begin{array}{l}\text { alpha-L- } \\
\text { Arabinopyrano } \\
\text { se }\end{array}$ & 2.4 & 104.0 & N/A & $<30$ & None & Bioactive & $\begin{array}{l}\text { Induces Pbad promoter } \\
\text { expression in E. coli }\end{array}$ \\
\hline NCGC00351072 & ML414 & 3.2 & 79.6 & N/A & $<30$ & None & Bioactive & $\begin{array}{l}\text { Oligosaccharyltransferase } \\
\text { inhibitor }\end{array}$ \\
\hline NCGC00379165 & $\begin{array}{l}\text { IT1t } \\
\text { dihydrochloride }\end{array}$ & 3.5 & 96.3 & N/A & $<30$ & None & Bioactive & CXCR4 inhibitor \\
\hline NCGC00485648 & $\begin{array}{l}\text { S-15176 } \\
\text { difumarate salt }\end{array}$ & 3.8 & 127.4 & N/A & $<30$ & None & Bioactive & Oxidative Stress Inhibitor \\
\hline NCGC00384450 & $\begin{array}{l}\text { JTV519 } \\
\text { Hemifumarate }\end{array}$ & 5.5 & 85.7 & N/A & $<30$ & None & Clinical trial & $\begin{array}{l}\text { Ryanodine receptor (RyR) } \\
\text { inhibitor }\end{array}$ \\
\hline NCGC00253604 & Rescimetol & 8.9 & 81.8 & N/A & $<30$ & None & $\begin{array}{l}\text { Approved } \\
\text { outside of US }\end{array}$ & Antihypertensive agent \\
\hline NCGC00164559 & $\begin{array}{l}\text { Duloxetine } \\
\text { hydrochloride }\end{array}$ & 10.0 & 90.0 & N/A & $<30$ & $\begin{array}{l}\text { Mpro assay } \\
\text { (Vatansever et al., } \\
\text { 2020) }\end{array}$ & FDA & $\begin{array}{l}\text { Norepinephrine reuptake } \\
\text { inhibitor; Serotonin- } \\
\text { norepinephrine reuptake } \\
\text { inhibitor (SNRI) }\end{array}$ \\
\hline NCGC00181168 & $\begin{array}{l}\text { Trifluomeprazi } \\
\text { ne } 2 \text { - } \\
\text { butenedioate }\end{array}$ & 10.0 & 90.2 & N/A & $<30$ & None & Bioactive & Antipsychotic Agents \\
\hline NCGC00169804 & $\begin{array}{l}\text { Asteriscunolide } \\
\text { D }\end{array}$ & 10.0 & 93.3 & N/A & $<30$ & None & Bioactive & Natural product \\
\hline NCGC00485925 & $\begin{array}{l}\text { Genz-123346 } \\
\text { (free base) }\end{array}$ & 10.0 & 99.4 & N/A & $<30$ & $\begin{array}{l}\text { In vitro live virus } \\
\text { (Vitner et al., 2020) }\end{array}$ & Bioactive & $\begin{array}{l}\text { Ceramide glucosyltransferase } \\
\text { Inhibitor }\end{array}$ \\
\hline NCGC00015708 & $\begin{array}{l}\text { Maprotiline } \\
\text { hydrochloride }\end{array}$ & 10.0 & 103.7 & N/A & $<30$ & $\begin{array}{l}\text { Virtual: Mpro } \\
\text { docking (Chauhan, } \\
\text { 2020) }\end{array}$ & FDA & $\begin{array}{l}\text { Norepinephrine reputake } \\
\text { inhibitor; Tricyclic } \\
\text { antidepressant }\end{array}$ \\
\hline NCGC00168786 & Deserpidine & 10.0 & 84.7 & N/A & $<30$ & $\begin{array}{l}\text { Virtual: NSP16 } \\
\text { docking (Jiang et } \\
\text { al., 2020) }\end{array}$ & FDA & $\begin{array}{l}\text { Angiotensin converting enzyme } \\
\text { inhibitor }\end{array}$ \\
\hline
\end{tabular}




\begin{tabular}{|c|c|c|c|c|c|c|c|c|}
\hline NCGC00015096 & $\begin{array}{l}\text { Amiodarone } \\
\text { hydrochloride }\end{array}$ & 10.0 & 100.5 & N/A & $<30$ & $\begin{array}{l}\text { Clinical (Castaldo et } \\
\text { al., 2020) }\end{array}$ & FDA & Potassium channel blocker \\
\hline NCGC00181088 & $\begin{array}{l}\text { Melitracen } \\
\text { hydrochloride }\end{array}$ & 10.0 & 97.1 & N/A & $<30$ & None & $\begin{array}{l}\text { Approved } \\
\text { outside of US }\end{array}$ & $\begin{array}{l}\text { Antidepressive Agents, } \\
\text { Tricyclic; }\end{array}$ \\
\hline NCGC00015428 & $\begin{array}{l}(+/-)- \\
\text { Fluoxetine }\end{array}$ & 10.0 & 115.8 & N/A & $<30$ & $\begin{array}{l}\text { In vitro live virus } \\
\text { (Zimniak et al., } \\
\text { 2020) }\end{array}$ & FDA & $\begin{array}{l}\text { Selective serotonin reuptake } \\
\text { inhibitor (SSRI) }\end{array}$ \\
\hline NCGC00018102 & Flunarizine & 10.0 & 94.1 & N/A & $<30$ & $\begin{array}{l}\text { Virtual: Spike } \\
\text { docking } \\
\text { (Chernyshev, 2020) }\end{array}$ & $\begin{array}{l}\text { Approved } \\
\text { outside of US }\end{array}$ & Calcium channel blocker \\
\hline NCGC00183024 & Proglumetacin & 10.0 & 87.6 & N/A & $<30$ & None & $\begin{array}{l}\text { Approved } \\
\text { outside of US }\end{array}$ & Cyclooxygenase inhibitor \\
\hline NCGC00378760 & DMP 777 & 10.0 & 92.5 & N/A & $<30$ & None & Clinical trial & Leukocyte elastase Inhibitor \\
\hline NCGC00476094 & Dexanabinol & 10.0 & 110.8 & N/A & $<30$ & None & Clinical trial & NMDA antagonist \\
\hline
\end{tabular}




\section{References}

(2020). Coronavirus Antiviral Research Database [Online]. Stanford University. Available:

https://covdb.stanford.edu/search/?compound=Remdesivir\&target=Polymerase [Accessed 5 Aug 2020].

Barnard, D.L., Day, C.W., Bailey, K., Heiner, M., Montgomery, R., Lauridsen, L., et al. (2008). Is the antipsychotic, 10-(3-(dimethylamino)propyl)phenothiazine (promazine), a potential drug with which to treat SARS infections? Antiviral Research 79(2), 105-113. doi: 10.1016/j.antiviral.2007.12.005.

Beigel, J.H., Tomashek, K.M., Dodd, L.E., Mehta, A.K., Zingman, B.S., Kalil, A.C., et al. (2020). Remdesivir for the Treatment of Covid-19 - Preliminary Report. N Engl J Med. doi: 10.1056/NEJMoa2007764.

Brimacombe, K.R., Zhao, T., Eastman, R.T., Hu, X., Wang, K., Backus, M., et al. (2020). An OpenData portal to share COVID-19 drug repurposing data in real time. bioRxiv. doi: 10.1101/2020.06.04.135046.

Castaldo, N., Aimo, A., Castiglione, V., Padalino, C., Emdin, M., and Tascini, C. (2020). Safety and Efficacy of Amiodarone in a Patient With COVID-19. JACC: Case Reports 2(9), 1307-1310. doi: 10.1016/j.jaccas.2020.04.053.

Chauhan, N. (2020). Possible Drug Candidates for COVID-19. ChemRxiv. doi: 10.26434/chemrxiv.11985231.v1.

Chernyshev, A. (2020). Pharmaceutical Targeting the Envelope Protein of SARS-CoV-2: the Screening for Inhibitors in Approved Drugs. ChemRxiv. doi: 10.26434/chemrxiv.12286421.v1.

Dittmar, M., Lee, J.S., Whig, K., Segrist, E., Li, M., Jurado, K., et al. (2020). Drug repurposing screens reveal FDA approved drugs active against SARS-Cov-2. bioRxiv. doi: 10.1101/2020.06.19.161042.

Dong, E., Du, H., and Gardner, L. (2020). An interactive web-based dashboard to track COVID-19 in real time. Lancet Infect Dis 20(5), 533-534. doi: 10.1016/S1473-3099(20)30120-1.

Dwivedy, A., Mariadasse, R., Ahmed, M., Kar, D., Jeyakanthan, J., and Biswal, B.K. (2020). In silico characterization of the NiRAN domain of RNA-dependent RNA polymerase provides insights into a potential therapeutic target against SARS-CoV2. OSF Preprints. doi: 10.31219/osf.io/wd6zu.

Eastman, R.T., Roth, J.S., Brimacombe, K.R., Simeonov, A., Shen, M., Patnaik, S., et al. (2020). Remdesivir: A Review of Its Discovery and Development Leading to Emergency Use Authorization for Treatment of COVID-19. ACS Cent Sci 6(5), 672-683. doi: 10.1021/acscentsci.0c00489.

Ellinger, B., Bojkova, D., Zaliani, A., Cinatl, J., Claussen, C., Westhaus, S., et al. (2020). Identification of inhibitors of SARS-CoV-2 in-vitro cellular toxicity in human (Caco-2) cells using a large scale drug repurposing collection. Research Square. doi: 10.21203/rs.3.rs-23951/v1.

EMA (2020). "Summary on Compassionate Use: Remdesivir Gilead", (ed.) H.M. Division.).

Eslami Shahrbabaki, M., Dehnavieh, R., Vali, L., and Sharafkhani, R. (2018). Chlorpromazine versus piperacetazine for schizophrenia. Cochrane Database of Systematic Reviews. doi: 10.1002/14651858.CD011709.pub2.

Grzybowski, B., Grynkiewicz, G., Szymkuć, S., Molga, K., Wołos, A., Gajewska, E.P., et al. (2020). Suggestions for second-pass anti-COVID-19 drugs based on the Artificial Intelligence measures of molecular similarity, shape and pharmacophore distribution. ChemRxiv. doi: 10.26434/chemrxiv.12084690.v2.

Heaton, N.S. (2017). Revisiting the concept of a cytopathic viral infection. PLoS Pathog 13(7), e1006409. doi: 10.1371/journal.ppat.1006409. 
Huang, R., Xu, M., Zhu, H., Chen, C.Z., Lee, E.M., He, S., et al. (2020). Massive-scale biological activitybased modeling identifies novel antiviral leads against SARS-CoV-2. bioRxiv. doi: 10.1101/2020.07.27.223578.

Huang, R., Zhu, H., Shinn, P., Ngan, D., Ye, L., Thakur, A., et al. (2019). The NCATS Pharmaceutical Collection: a 10-year update. Drug Discov Today 24(12), 2341-2349. doi: 10.1016/j.drudis.2019.09.019.

Inglese, J., Auld, D.S., Jadhav, A., Johnson, R.L., Simeonov, A., Yasgar, A., et al. (2006). Quantitative highthroughput screening: a titration-based approach that efficiently identifies biological activities in large chemical libraries. Proc Natl Acad Sci U S A 103(31), 11473-11478. doi: 10.1073/pnas.0604348103.

Jeon, S., Ko, M., Lee, J., Choi, I., Byun, S.Y., Park, S., et al. (2020). Identification of Antiviral Drug Candidates against SARS-CoV-2 from FDA-Approved Drugs. Antimicrob Agents Chemother 64(7). doi: 10.1128/AAC.00819-20.

Jiang, Y., Liu, L., Manning, M., Bonahoom, M., Lotvola, A., and Yang, Z.-Q. (2020). Repurposing Therapeutics to Identify Novel Inhibitors Targeting 2'-O-Ribose Methyltransferase Nsp16 of SARS-CoV-2. ChemRxiv. doi: 10.26434/chemrxiv.12252965.v1.

Kouznetsova, J., Sun, W., Martínez-Romero, C., Tawa, G., Shinn, P., Chen, C.Z., et al. (2019). Identification of 53 compounds that block Ebola virus-like particle entry via a repurposing screen of approved drugs. Emerging Microbes \& Infections 3(1), 1-7. doi: 10.1038/emi.2014.88.

Lin, G.L., Wilson, K.M., Ceribelli, M., Stanton, B.Z., Woo, P.J., Kreimer, S., et al. (2019). Therapeutic strategies for diffuse midline glioma from high-throughput combination drug screening. $S c i$ Transl Med 11(519). doi: 10.1126/scitranslmed.aaw0064.

Ma, C., Sacco, M.D., Hurst, B., Townsend, J.A., Hu, Y., Szeto, T., et al. (2020). Boceprevir, GC-376, and calpain inhibitors II, XII inhibit SARS-CoV-2 viral replication by targeting the viral main protease. bioRxiv. doi: 10.1101/2020.04.20.051581.

Morales-Ortega, A., Bernal-Bello, D., Llarena-Barroso, C., Frutos-Pérez, B., Duarte-Millán, M.Á., García de Viedma-García, V., et al. (2020). Imatinib for COVID-19: A case report. Clinical Immunology 218. doi: 10.1016/j.clim.2020.108518.

Ou, X., Liu, Y., Lei, X., Li, P., Mi, D., Ren, L., et al. (2020). Characterization of spike glycoprotein of SARSCoV-2 on virus entry and its immune cross-reactivity with SARS-CoV. Nat Commun 11(1), 1620. doi: 10.1038/s41467-020-15562-9.

Riva, L., Yuan, S., Yin, X., Martin-Sancho, L., Matsunaga, N., Pache, L., et al. (2020). Discovery of SARSCoV-2 antiviral drugs through large-scale compound repurposing. Nature. doi: $10.1038 / \mathrm{s} 41586-$ 020-2577-1.

Robey, R.W., Pluchino, K.M., Hall, M.D., Fojo, A.T., Bates, S.E., and Gottesman, M.M. (2018). Revisiting the role of $A B C$ transporters in multidrug-resistant cancer. Nat Rev Cancer 18(7), 452-464. doi: 10.1038/s41568-018-0005-8.

Ryu, Y.B., Park, S.-J., Kim, Y.M., Lee, J.-Y., Seo, W.D., Chang, J.S., et al. (2010). SARS-CoV 3CLpro inhibitory effects of quinone-methide triterpenes from Tripterygium regelii. Bioorganic \& Medicinal Chemistry Letters 20(6), 1873-1876. doi: 10.1016/j.bmcl.2010.01.152.

Schrijver, E.J.M., de Graaf, K., de Vries, O.J., Maier, A.B., and Nanayakkara, P.W.B. (2016). Efficacy and safety of haloperidol for in-hospital delirium prevention and treatment: A systematic review of current evidence. European Journal of Internal Medicine 27, 14-23. doi: 10.1016/j.ejim.2015.10.012.

Shrimp, J.H., Kales, S.C., Sanderson, P.E., Simeonov, A., Shen, M., and Hall, M.D. (2020). An Enzymatic TMPRSS2 Assay for Assessment of Clinical Candidates and Discovery of Inhibitors as Potential Treatment of COVID-19. bioRxiv. doi: 10.1101/2020.06.23.167544. 
Shyr, Z.A., Gorshkov, K., Chen, C.Z., and Zheng, W. (2020). Drug discovery strategies for SARS-CoV-2. J Pharmacol Exp Ther. doi: 10.1124/jpet.120.000123.

Sivaraman, P., Rattehalli, R.D., and Jayaram, M.B. (2010). Levomepromazine for schizophrenia. Cochrane Database of Systematic Reviews. doi: 10.1002/14651858.CD007779.pub2.

Touret, F., Gilles, M., Barral, K., Nougairède, A., Decroly, E., de Lamballerie, X., et al. (2020). In vitro screening of a FDA approved chemical library reveals potential inhibitors 1 of SARS-CoV-2 replication. bioRxiv. doi: 10.1101/2020.04.03.023846.

Vatansever, E.C., Yang, K., Kratch, K.C., Drelich, A., Cho, C.-C., Mellot, D.M., et al. (2020). Targeting the SARS-CoV-2 Main Protease to Repurpose Drugs for COVID-19. bioRxiv. doi: 10.1101/2020.05.23.112235.

Vitner, E.B., Avraham, R., Achdout, H., Tamir, H., Agami, A., Cherry, L., et al. (2020). Antiviral activity of Glucosylceramide synthase inhibitors against SARS-CoV-2 and other RNA virus infections. bioRxiv. doi: 10.1101/2020.05.18.103283.

Wang, Y., Jadhav, A., Southal, N., Huang, R., and Nguyen, D.T. (2010). A grid algorithm for high throughput fitting of dose-response curve data. Curr Chem Genomics 4, 57-66. doi: $10.2174 / 1875397301004010057$.

Weston, S., Coleman, C.M., Haupt, R., Logue, J., Matthews, K., and Frieman, M.B. (2020). Broad anticoronaviral activity of FDA approved drugs against SARS-CoV-2 in vitro and SARS-CoV in vivo. bioRxiv. doi: 10.1101/2020.03.25.008482.

Zhu, H., Chen, C.Z., Sakamuru, S., Simeonov, A., Hall, M.D., Xia, M., et al. (2020a). Mining of high throughput screening database reveals AP-1 and autophagy pathways as potential targets for COVID-19 therapeutics. arXiv 2007.12242v1.

Zhu, W., Xu, M., Chen, C.Z., Guo, H., Shen, M., Hu, X., et al. (2020b). Identification of SARS-CoV-2 3CL Protease Inhibitors by a Quantitative High-throughput Screening. bioRxiv. doi: 10.1101/2020.07.17.207019.

Zimniak, M., Kirschner, L., Hilpert, H., Seibel, J., and Bodem, J. (2020). The serotonin reuptake inhibitor Fluoxetine inhibits SARS-CoV-2. bioRxiv. doi: 10.1101/2020.06.14.150490. 


\section{Figure 1}

A

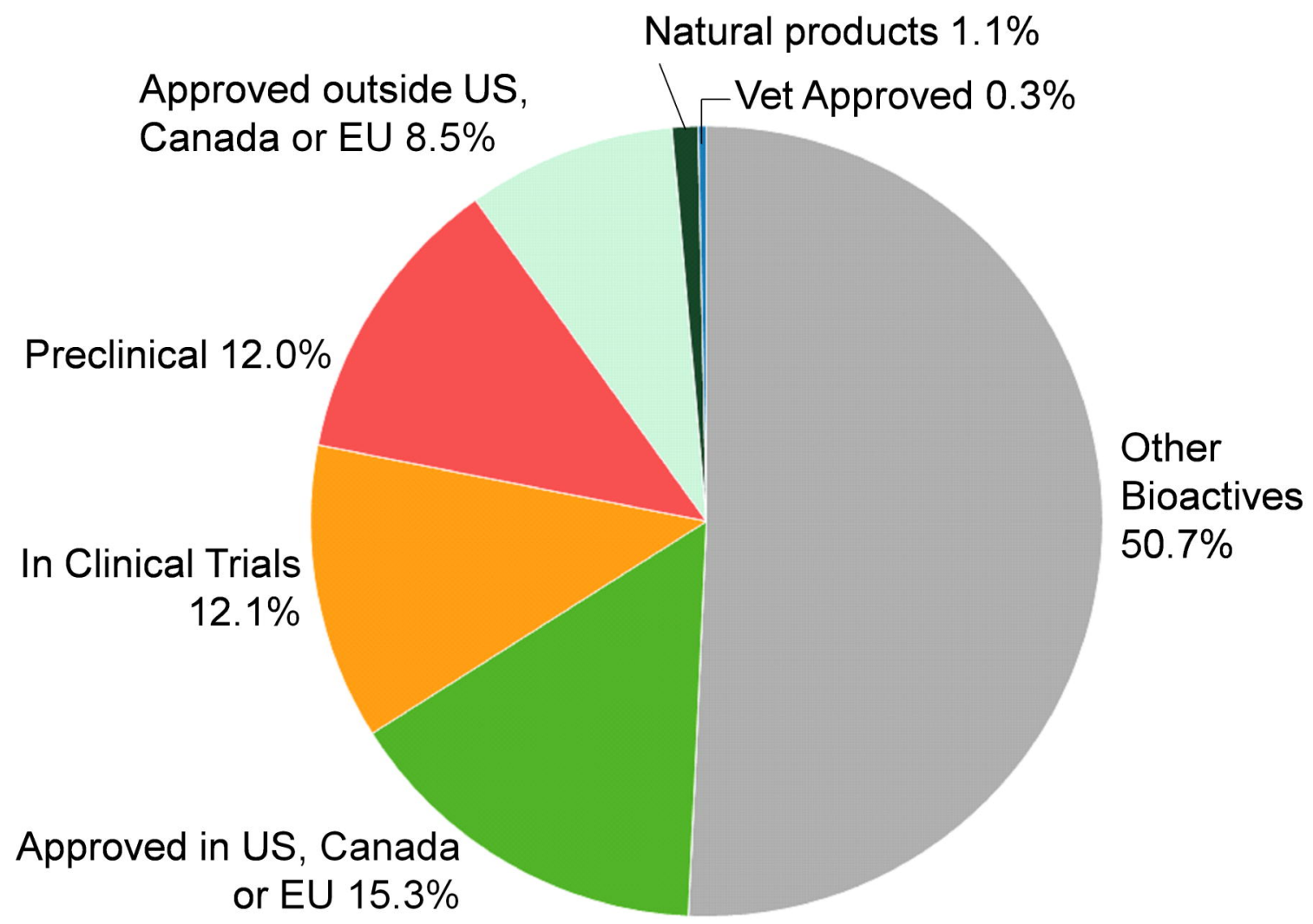

B

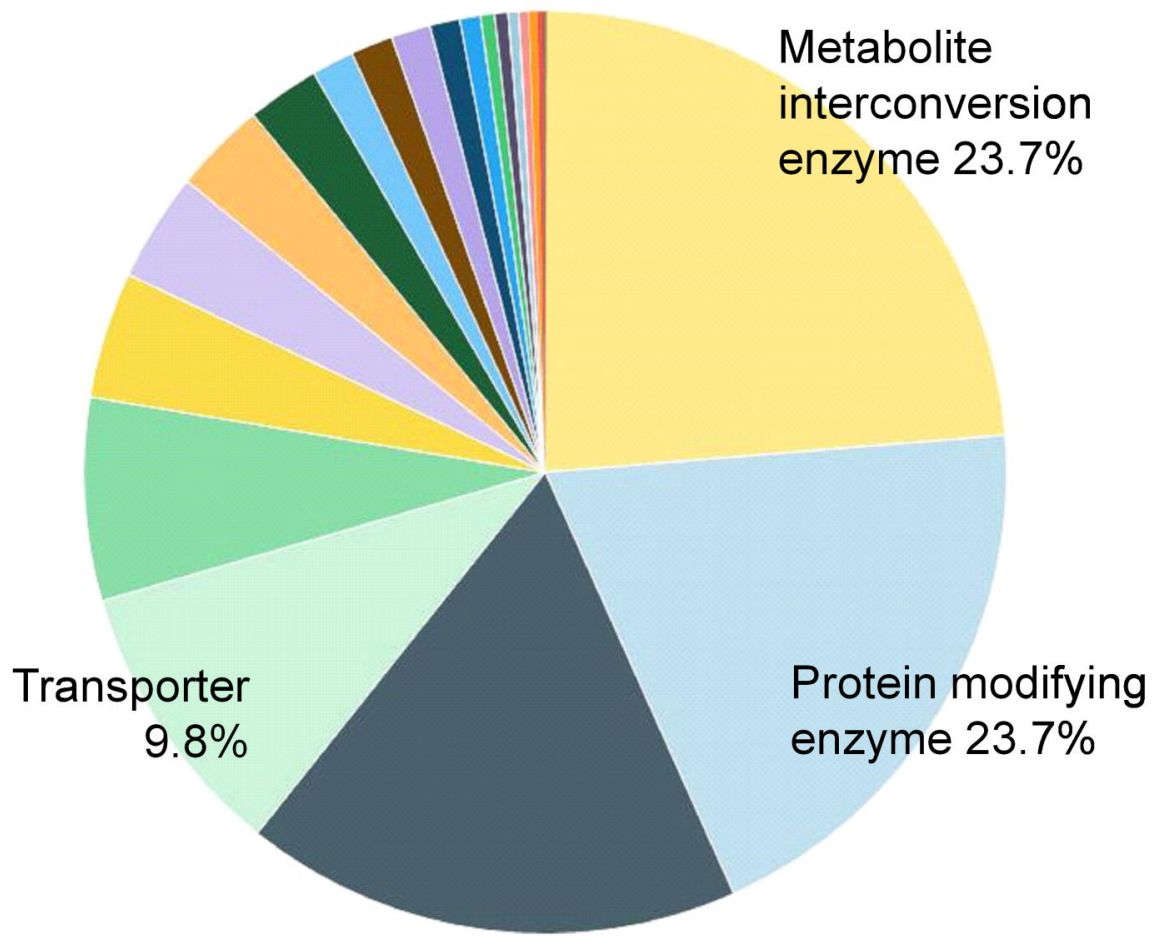

Transmembrane signal receptor $23.7 \%$
Color by

PANTHER Protein Class

calcium-binding protein

cell adhesion molecule

chaperone

chromatin/chromatin-binding, or -regulatory protein

cytoskeletal protein

defense/immunity protein

extracellular matrix protein

gene-specific transcriptional regulator

intercellular signal molecule

membrane traffic protein

metabolite interconversion enzyme

Non-human protein

nucleic acid binding protein

protein modifying enzyme

protein-binding activity modulator

scaffold/adaptor protein

storage protein

structural protein

transfer/carrier protein

translational protein

transmembrane signal receptor transporter 
Figure 2

a. Assay plate statistics

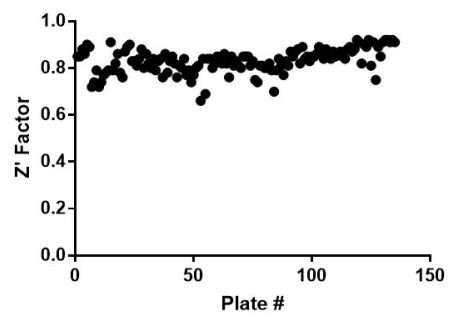

b. Control compound reproducibility



[Remdesivir], uM



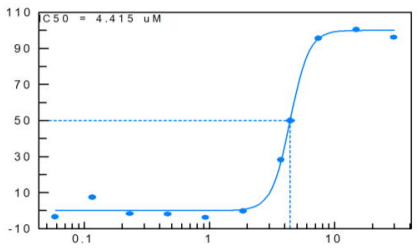

[Remdesivir], uM

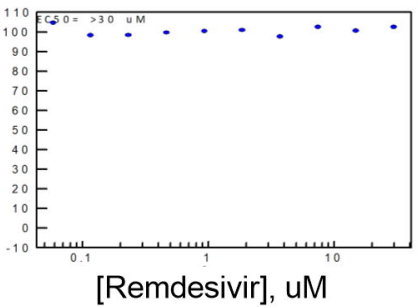



[Remdesivir], uM

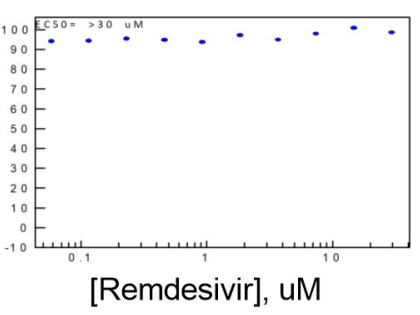


Figure 3

a. Autophagy modulators



c. Kinase modulators

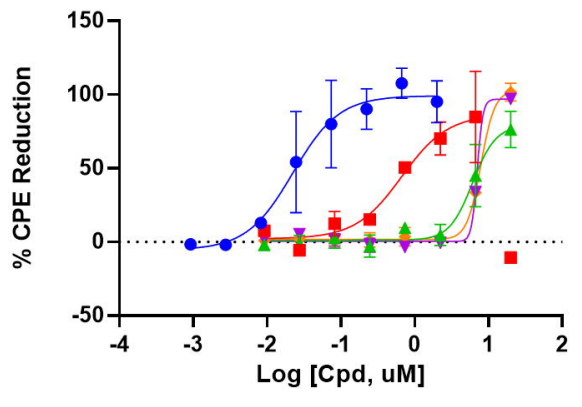

e. GPCR modulators: Serotonin receptors

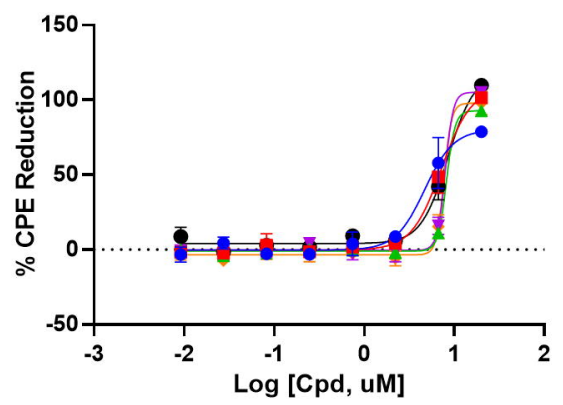

-- VPS34-IN1

- STF-62247

- VPS34 Inhibitor 1 b. Host protease inhibitors

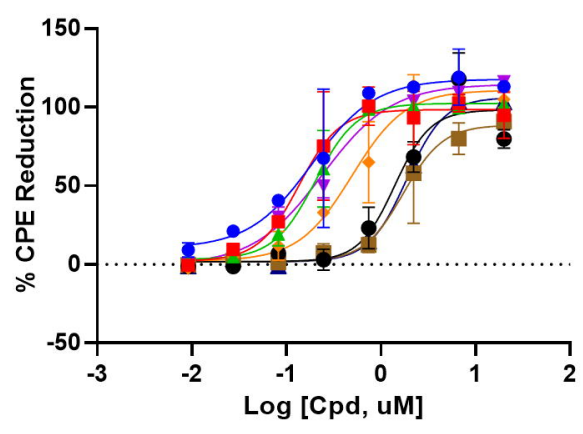

d. GPCR modulators: Opioid receptors

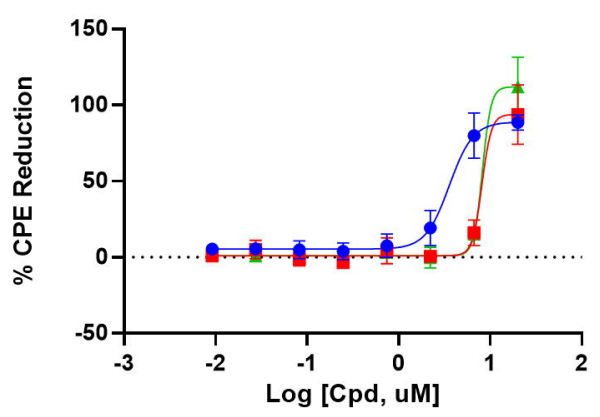

f. GPCR modulators: Histamine receptors

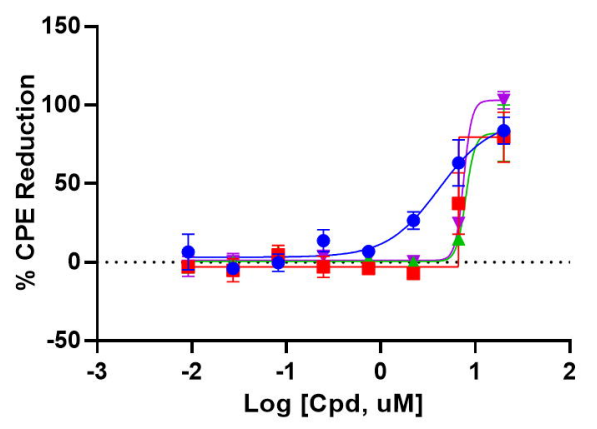

$\rightarrow$ Z-FA-FMK

-- VBY-825

- CAA-0225

_ Cathepsin Inhibitor I Z-Gly-Leu-Phe

- -Chloromethyl ketone

- Balicatib

- Calpeptin Calpain

- Inhibitor I ALLN
- Apilimod

- Berzosertib

- IKK-2 Inhibitor VIII

$\checkmark$ NSC 33994

- Imatinib
- N-Methyls-Piperone -hydrochloride

- GMC 2-29

- Lu AE58054

_. (R)-(-)-LY 426965 dihydrochloride

- GMC 2-113

SB 271046 hydrochloride

g. GPCR modulators: Dopamine receptor and others

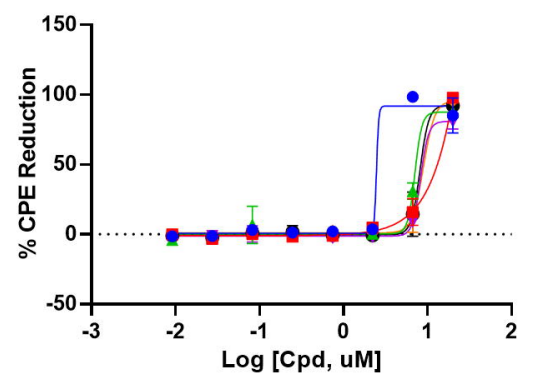

- GW 803430

- Piperacetazine

^ Chlorprothixene Methotrimeprazine maleat salt

- AM1241

- CpdD hydrochloride
Amodiaquin dihydrochloride

Clemastine fumarate

Methdilazine hydrochloride

$\rightarrow$ Difeterol Loperamide hydrochloride Naltrindol isothiocyanate hydrochloride 